\title{
POTENSI PELUANG DEMAM BERDARAH DENGUE (DBD) BERDASARKAN PROYEKSI PERUBAHAN IKLIM (STUDY KASUS : DKI JAKARTA)
}

\section{POTENCY OF PROBABILITY FOR DENGUE HERMOLOGIC FEVER (DHF) ACCORDING TO CLIMATE CHANGE PROJECTION (CASE STUDY : DKI JAKARTA)}

\author{
Dede Tarmana
}

\begin{abstract}
Abstrak :Pengaruh perubahan iklim terhadap demam berdarah dengue (DBD) bersifat tidak langsung. Hal ini karena terdapat faktor perantara penyebab yaitu nyamuk Aedes Aegypti. Perkembangbiakan dan siklus hidup nyamuk Aedes Aegypti inilah yang dipengaruhi langsung oleh kondisi iklim. Kesesuaian iklim dengan lingkungan hidup nyamuk aedes Aegypti ditandai dengan temperatur hangat dan curah hujan tinggi seperti Indonesia. Tujuan dari penelitian ini yaitu untuk mengetahui proyeksi peluang DBD secara rata-rata untuk periode 20142038 berdasarkan proyeksi curah hujan dan temperatur. Metode statistik yang digunakan untuk mengetahui pengaruh iklim terhadap kesehatan (demam berdarah) antara lain statistik downscaling, analisis komponen utama, dan regresi logistik ordinal. Hasil analisis menunjukan bahwa curah hujan yang sesuai dengan demam berdarah berkisar 100-300 mm. Untuk curah hujan relatif tinggi $120-317 \mathrm{~mm}$ yang terjadi pada bulan JanuariFebruari, ancaman paling kuat adalah bahaya banjir dan DBD. Untuk temperatur udara, proyeksi ke depan (2014-2038) berkisar antara $26-30{ }^{\circ} \mathrm{C}$, kondisi ini masih optimal untuk perkembangan nyamuk Aedes Aegypti. Proyeksi peluang demam berdarah berdasarkan proyeksi curah hujan dan temperatur menunjukan wilayah Jakarta masih berpeluang tinggi sebagai wilayah katagori resiko tinggi demam berdarah dengan nilai peluang $0,74-0,99$.
\end{abstract}

Kata Kunci : Perubahan iklim, Demam berdarah, Logistik ordinal, Peluang.

Abstract : Influence of climate change to Dengue hermologic fever(DHF) has indirect characteristic. There are other factor as medium DHF case, that is aedes Aegypti mosquito. Life cycle and breeding of aedes Aegypti mosquito has direct contact with climate condition. Suitability between climate and life environment of aedes Aegypti mosquito marked with warm temperature and heavy rainfall like Indonesia. The purpose of this study to know projection of DHF average probability period 2013-2038 base on rainfall and temperature projection. Statistical method, such as downscalling statistic, principal component analysis and ordinal logistic regression was applied to know impact of climate on health (dengue cases). Result of analysis shows suitability between rainfall with DHF case is $100-300 \mathrm{~mm}$. January-February has heavy rainfall $120-317 \mathrm{~mm}$, so needed attention more and more stressing about flood disaster and DHF case. In the period of 2014-2038, interval temperatur occurred between $26-30^{\circ} \mathrm{C}$. The interval temperature like this is optimal condition for Aedes Aegypti breeding. The result of probability projection shows that Jakarta is still the region for high risk DHF, with probability value $0,74-0,99$

Keywords : Climate change, Dengue hermologic fever, Ordinal logistic, Probability.

Korespondensi : Pusat Perubahan Iklim dan Kualitas Udara BMKG

JI Angkasa I No 2 Kemayoran Jakarta Pusat 10720 Indonesia

Email : tarmana_dede@yahoo.com

\section{PENDAHULUAN}

Laporan hasil kajian Intergovermental Panel for Climate Change (IPCC) yang ke-4 (Assessment Report $4 \approx$ AR4) pada Tahun 2007 mengatakan bahwa suhu permukaan global meningkat sebesar $0,74 \pm 0,32{ }^{0} \mathrm{C}$ selama abad ke-20. ${ }^{1}$
Secara dominan penyebab kejadian ini adalah adanya kenaikan yang tajam dari konsentrasi gas rumah kaca $\left(\mathrm{GRK} \approx \mathrm{CO}_{2}\right.$, $\left.\mathrm{CH}_{4}, \mathrm{~N}_{2} \mathrm{O}, \mathrm{CHF}_{3}, \mathrm{SF}_{6}, \mathrm{CF}_{4}\right)$ sebagai dampak aktivitas manusia. Bukti adanya kenaikan suhu permukaan bumi ditandai dengan melelehnya lapisan es di berbagai wilayah daratan (misal : Puncak Jaya Wijaya Papua). ${ }^{2}$ Selain itu bukti lainnya adalah BMKG mencatat data temperatur bulan Juli di Jakarta telah mengalami peningkatan sebesar $1,4{ }^{\circ} \mathrm{C}$ dalam kurun waktu 100 tahun terakhir. ${ }^{3}$ 
Hal yang perlu di waspadai dari fenomena perubahan iklim dan menjadi pemikiran para ahli adalah dampak yang ditimbulkan. Beberapa informasi menunjukan bahwa seiring dengan terjadinya fenomena ini maka akan terjadi peningkatan frekuensi bencana alam banjir, longsor, kekeringan, gelombang panas, badai, dan wabah penyakit (Malaria, Dengue Hermologic Fever). ${ }^{4}$ Menurut United States Environmental Protection Agency beberapa sektor kehidupan yang berpotensi terkena dampak perubahan iklim antara lain sektor kesehatan, pertanian, kehutanan, sumber daya air, infrastruktur, area pantai, perikanan, dan lingkungan alami lainnya. ${ }^{5}$ Pada konvensi tahun 2007, IPCC mengeluarkan laporan yang berkaitan dengan dampak perubahan iklim terhadap bidang kesehatan. Secara umum salah satu isi laporannya berisi bahwa perubahan iklim akan mengubah distribusi beberapa jenis nyamuk (Malaria dan Aedes Aegypti) dan penyakitpenyakit menular lainnya. ${ }^{1}$

Menurut organisasi kesehatan dunia (WHO) wilayah Indonesia merupakan wilayah endemik terhadap beberapa penyakit yaitu cholera, demam berdarah, dan malaria. ${ }^{6}$ Sehingga dengan kondisi ini masyarakat Indonesia harus selalu waspada terhadap ancaman beberapa vektor penyakit di atas, terlebih dengan adanya perubahan iklim. Secara teoritis negara-negara yang beriklim tropis mempunyai temperatur yang hangat dengan variabilitas curah hujan tinggi sebagai lingkungan nyaman untuk kehidupan vektor seperti nyamuk Aedes Aegypti. Tarmana ${ }^{7}$ dalam penelitiannya di Jakarta menyebutkan bahwa puncak kejadian demam berdarah terjadi pada interval temperatur $27-29^{\circ} \mathrm{C}$.

Kementerian kesehatan dalam memberikan informasi tentang kasus demam berdarah dengue (DBD) mengklasifikasikan ke dalam 3 (tiga) tingkatan resiko, yaitu : resiko tinggi (kasus DBD > 55), resiko menengah (20 $<$ kasus $\mathrm{DBD}<55$ ) dan resiko rendah (kasus < 20). Dengan tingkat kepadatan penduduk yang tinggi dan kondisi iklim serta lingkungan yang mempunyai kesesuaian untuk pertumbuhan nyamuk, maka Jakarta rentan dalam kategori wilayah dengan resiko tinggi DBD. ${ }^{8}$

Secara demografi dan topografi Jakarta terletak pada posisi koordinat $5^{\circ} 19^{\prime} 12^{\prime \prime}-6^{\circ} 23^{\prime} 54^{\prime \prime}$ LS dan $106^{\circ} 22^{\prime} 42^{\prime \prime}$ $106^{\circ} 58^{\prime} 48^{\prime \prime}$ dengan tingkat kepadatan penduduk yang cukup tinggi serta memiliki topografi secara umum relatif datar dengan rata-rata ketinggian $8 \mathrm{~m}$ dpl (diatas permukaan laut) tanpa ada pegunungan, dilalui oleh 13 sungai mengalir dari daerah penopang Jakarta dan bermuara di laut Jawa yang bersinggungan langsung dengan pantai Jakarta Utara. Kondisi karakteristik wilayah seperti ini memungkinkan adanya bencana-bencana yang berkaitan dengan aliran air (bencana banjir) akibat dari curah hujan wilayah Jakarta sendiri dan kiriman dari luar daerah Jakarta. Dari gambaran kondisi geografi dan demografi serta klimatologis dimana wilayahnya relatif datar, kepadatan penduduk tinggi serta mempunyai temperatur optimum untuk perkembangan nyamuk aedes Aegypti ditambah penunjang genangan curah hujan sebagai tempat perkembangbiakannya, maka diyakini kalau Jakarta mempunyai kerentanan pada sektor kesehatan sebagai dampak dari perubahan iklim ${ }^{9}$ Berdasarkan kondisi Jakarta dan adanya laporan IPCC yang menyebutkan bahwa perubahan iklim (peningkatan suhu) akan meningkatkan peluang terjadi penyakit tular vektor (contoh : DBD), maka perlu dilakukan kajian seberapa besar peluang kejadian kasus DBD dimasa yang akan datang berdasarkan informasi skenario perubahan iklim (suhu udara dan curah hujan), hal ini menjadi enting guna perencanaan dalam program menghadapi kasus DBD

Dari uraian di atas, penelitian ini mempunyai rumusan masalah bagaimana hubungan antara unsur iklim dengan kasus demam berdarah yang terjadi serta bagaimana proyeksi peluang kejadian demam berdarah di masa yang akan datang berdasarkan proyeksi perubahan iklim untuk periode 2014-2038. Adapun tujuan penelitian ini adalah untuk mendapatkan gambaran proyeksi ke 
depan tentang peluang kejadian demam berdarah berdasarkan proyeksi perubahan iklim skenario $\mathrm{A} 1 \mathrm{~B}$ periode 2014-2038, sehingga gambaran ini dapat menjadi masukan untuk perencanaan langkah-langkah kebijakan yang harus diambil. Pemilihan periode dan skenario proyeksi perubahan iklim ini di sesuaikan dengan rencana pembangunan jangka panjang (25 tahun) dan kebijakan optimis pemerintah Indonesia dalam mereduksi karbon untuk menahan laju perubahan iklim.

\section{METODE PENELITIAN}

Data yang digunakan untuk penelitian adalah data iklim rata-rata periode 19802010 curah hujan $(\mathrm{CH})$ dan temperatur $(\mathrm{T})$ Stasiun pengamatan Pondok Betung, Kemayoran dan Tanjung Priok yang bersumber dari Badan Meteorologi Klimatologi dan Geofisika (BMKG), data proyeksi perubahan iklim skenario A1B periode 2014-2038 resolusi 20 × $20 \mathrm{~km}$ dari MRI (Meteorology Research Institute) Jepang dan data kejadian kasus DBD periode 2002-2010 dari Dinas Kesehatan propinsi DKI Jakarta.

Sesuai dengan penelitian sebelumnya yang sudah dilakukan tarmana (2010) dan rumusan masalah serta tujuan penelitian, maka untuk mewujudkannya digunakan beberapa metode penelitian yaitu :

- Metode Statistik Downscalling ${ }^{11}$ digunakan mendapatkan data proyeksi domain area penelitian (Jakarta) dari data iklim global MRI.

- Metode PCA (Principal Component Analysis) untuk mereduksi beberapa variabel unsur iklim dari berbagai stasiun di propinsi DKI Jakarta sehingga mndapatkan 1 (satu) peubah baru yang dapat memberikan gambaran umum Iklim Jakarta dengan proporsi di atas $50 \% .^{12,17}$

- Model Regresi Logistik Ordinal digunakan untuk menghitung proyeksi peluang DBD berdasarkan proyeksi curah hujan dan temperatur udara periode 2014-2038. ${ }^{13,16}$

Persamaan untuk menghitung proyeksi peluang resiko demam berdarah berdasarkan curah hujan dan temperatur:

$$
\begin{aligned}
& \pi_{1}=\frac{\mathrm{e}^{\left(-4,135+\left(0995 x P C A_{P 2}\right)-\left(0,275 x P C A_{T 2}\right)\right.}}{1+\mathrm{e}^{\left(-4,135+\left(0995 x P C A_{P 2}\right)-\left(0,275 x P C A_{T 2}\right)\right.}} \cdots \cdots \ldots \ldots \ldots . . . \\
& \pi_{2}=\frac{\mathrm{e}^{\left(-2,436\left(0,995 x P C A_{P 2}\right)-\left(0,275 x P C A_{T 2}\right)\right.}}{1+\mathrm{e}^{\left(-2,436+\left(0,995 x P C A_{P 2}\right)-\left(0,275 x P C A_{T 2}\right)\right.}}-\pi_{1} \\
& \pi_{3}=1-\pi_{2}
\end{aligned}
$$

Keterangan : $-\pi_{1}=$ Peluang DBD resiko rendah, $\pi_{2}=$ Peluang resiko menengah, $\Pi_{3}=$ Peluang resiko tinggi.

\section{HASIL}

\section{Proyeksi Temperatur Udara}

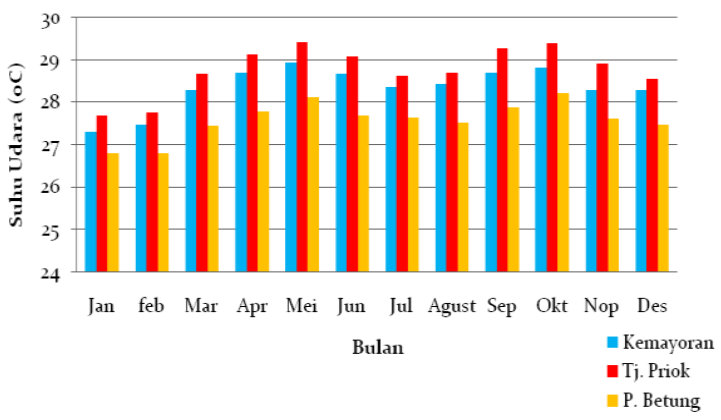

Gambar 1a. Proyeksi temperatur udara ratarata (2014-2038)

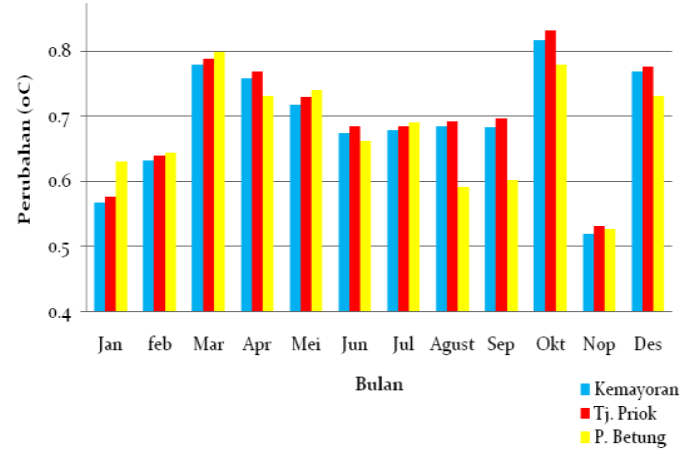

Gambar 1b. Perubahan proyeksi temperatur udara terhadap temperatur rata-rata saat ini

Gambar 1a. menunjukan hasil proyeksi temperatur udara Jakarta yang secara rata-rata terjadi peningkatan dengan interval $0,3^{\circ} \mathrm{C}$. Bila ditinjau dari waktu bulanan, peningkatan tertinggi terjadi pada bulan Maret dan Oktober (Gambar 1b.). Hal ini karena pada bulanbulan tersebut, posisi matahari berada di garis khatulistiwa untuk menuju kebelahan bumi bagian selatan dan utara. Sehingga energi matahari yang diterima oleh permukaan bumi lebih besar bila dibandingkan dengan bulan-bulan lainnya. 


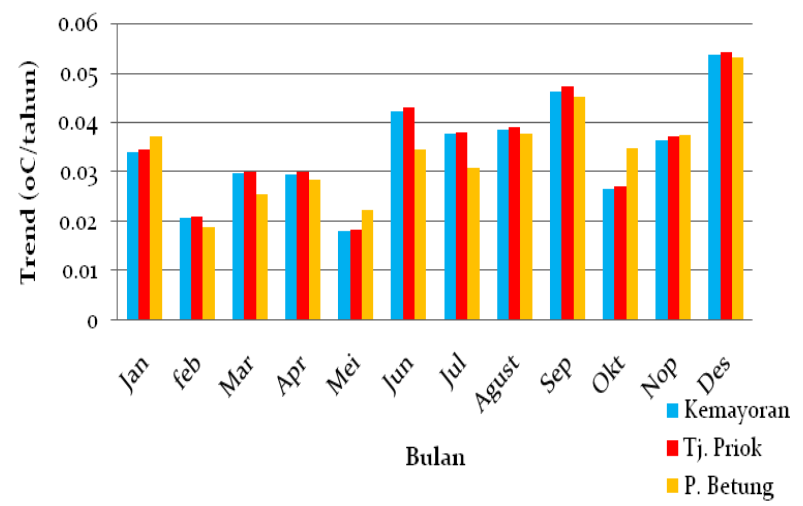

Gambar 2. Tren proyeksi temperatur udara (2014- 2038)

Gambar 2. menunjukan tren kenaikan temperatur udara setiap tahun pada masing-masing bulan dengan interval tren $0,03^{\circ} \mathrm{C}$. Nilai ini menunjukan bahwa berdasarkan data hasil proyeksi periode 2014-2038 akan terjadi kenaikan temperatur udara sebesar 0,03 satuan per tahun. Sehingga bila diambil tren linear maka pada akhir periode 2014-2038 akan terjadi kenaikan suhu sebesar $0,72^{\circ} \mathrm{C}$.

Secara spasial gambar 3. menunjukan bahwa varibilitas temperatur udara antar lokasi di DKI Jakarta relatif kecil. Selain antar lokasi, rangkaian peta pada gambar.3 yang disusun berdasarkan bulan ini di maksudkan hanya untuk memberikan kemudahan dalam melihat sedikit penjelasan sebaran temperatur yang tidak memiliki perbedaan terlalu jauh. Gambaran detail peta tersebut menjadi satu.

Peta proyeksi sebaran temperatur udara merupakan peta rata-rata temperatur yang diperoleh melalui hasil penurunan skala (teknik downscaling) dari Global Circulation Model (GCM) yang dikeluarkan oleh MRI jepang. Seperti telah dijelaskan sebelumnya bahwa berdasarkan referensi WMO (6) perkembangan nyamuk aedes Aegypti dipengaruhi oleh keadaan suhu dan curah hujan. Sehingga dengan mengetahui keadaan temperatur udara dan curah hujan dimasa yang akan datang, maka dapat menjadi acuan bagaimana peluang perkembangan vektor nyamuk penyebab kasus DBD. Di samping itu tindakan pencegahan dan kontrol vektor dapat lebih ditingkatkan. Berdasarkan informasi dari peta sebaran temperatur tentang kecilnya variabilitas temperatur antar lokasi, maka pola sebaran peluang DBD tidak akan berbeda jauh antar lokasi sejauh tidak ada perbedaan penanganan DBD antar lokasi.
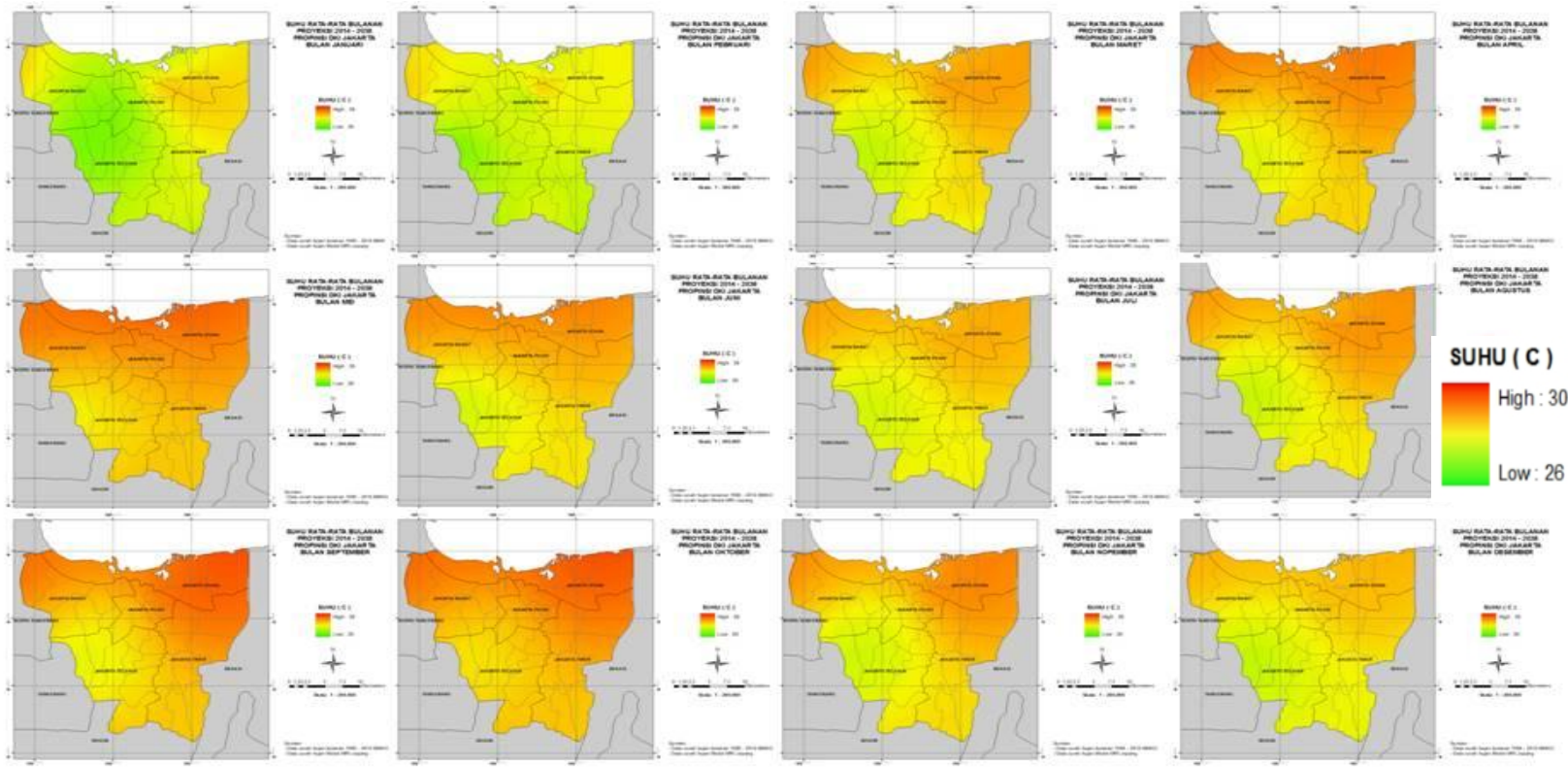

Gambar 3. Peta proyeksi temperatur udara rata-rata bulanan (2014-2038) 


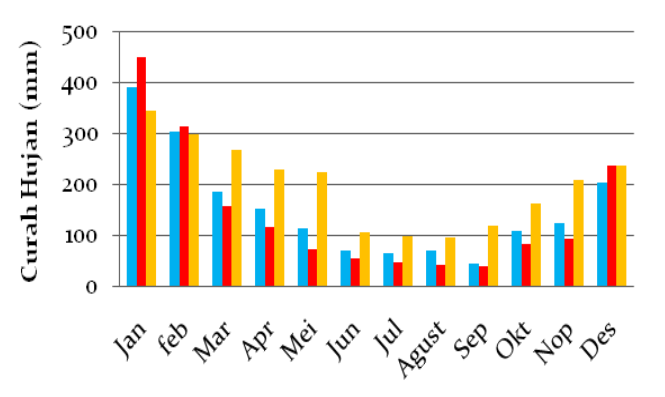

a

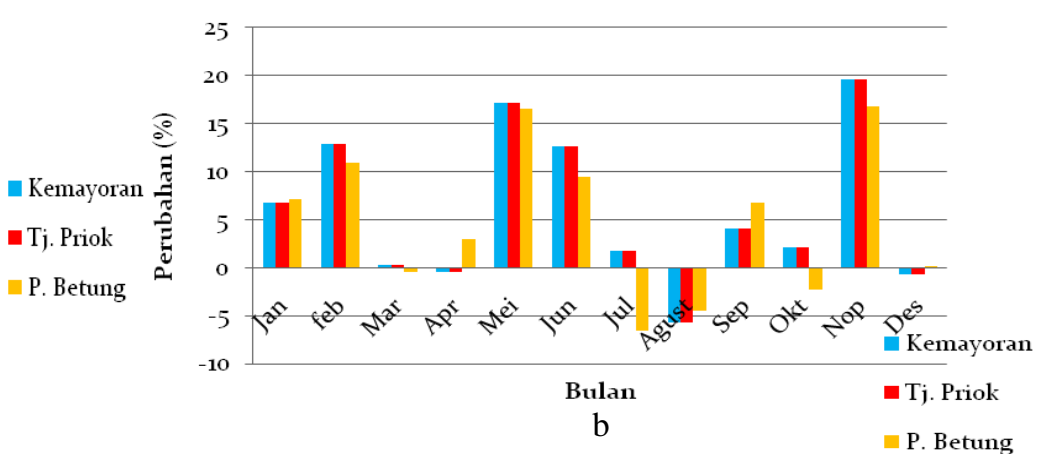

Gambar 4. a. Proyeksi curah hujan rata-rata bulanan (2014-2038), b. Perubahan CH proyeksi terhadap curah hujan rata-rata saat ini

\section{Proyeksi Curah Hujan}

Curah hujan di wilayah Jakarta memiliki tipe monsun, yaitu tipe hujan yang ditandai dengan grafik cekung dan memiliki 2 (dua) puncak hujan antara bulan November - Desember dan JanuariMaret. ${ }^{3}$ Hasil proyeksi $\mathrm{CH}$ pada gambar 4a. menunjukan kesamaan pola antara curah hujan hasil proyeksi dengan curah hujan rata-rata observasi. Hal ini berarti bahwa secara pola proyeksi curah hujan ke depan tidak mengalami perubahan. Namun bila dilihat besaran curah hujannya, maka ke depan untuk periode 2014-2038 ada perubahan besaran curah hujan yang variatif (Gambar 4b). Dimana sepanjang tahun ada bulan-bulan yang curah hujannya lebih kecil dari curah hujan rata-rata saat ini dan ada juga bulan-bulan yang curah hujannya lebih besar dari rata-rata saat ini.

Untuk bulan-bulan yang secara ratarata periode saat ini memilki curah hujan tinggi dan ke depan mengalami peningkatan, maka dapat dijadikan sebagai peringatan dini akan dampak yang ditimbulkannya. Bila dikaitkan dengan vektor penyakit (nyamuk aedes Aegypti), maka dengan adanya curah hujan yang cukup tinggi maka limpasan air akan menghanyutkan tempat-tempat perkembangan jentik sehingga dapat memutuskan rantai reproduksi nyamuk

Pada bulan yang memiliki curah hujan rata-rata rendah (April dan Mei) dan di proyeksi akan mengalami peningkatan seperti ditunjukan pada gambar.5, maka akan menyebabkan perubahan sebaran vektor penyakit. Hal ini dimungkinkan dengan adanya perubahan curah hujan akan tercipta lingkungan baru untuk perkembang- biakan nyamuk.

Peta proyeksi curah hujan seperti tampak pada gambar 6., menunjukan pola sebaran yang merata di seluruh wilayah Jakarta. Interval curah hujan yang terjadi berkisar antara 29,2-317,1 mm

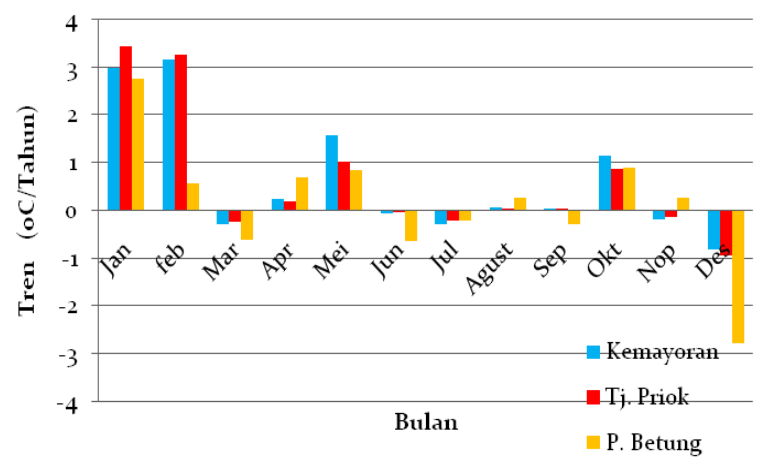

Gambar 5. Tren proyeksi temperatur udara rata-rata bulanan (2014- 2038)

Menurut Tarmana ${ }^{7}$ menyebutkan bahwa secara umum curah hujan yang mempunyai kesesuaian dengan kasus DBD berkisar antara $100-300$ mm. Maka dengan informasi ini, terdapat bulanbulan tertentu yang curah hujannya mempunyai kesesuaian dengan kasus DBD. Curah hujan Bulan November - Mei berkisar 100 - $300 \mathrm{~mm}$ yang berarti mempunyai kesesuaian untuk perkembangan kasus DBD (vektor nyamuk Aedes aegypti) dibanding bulanbulan lainnya. 


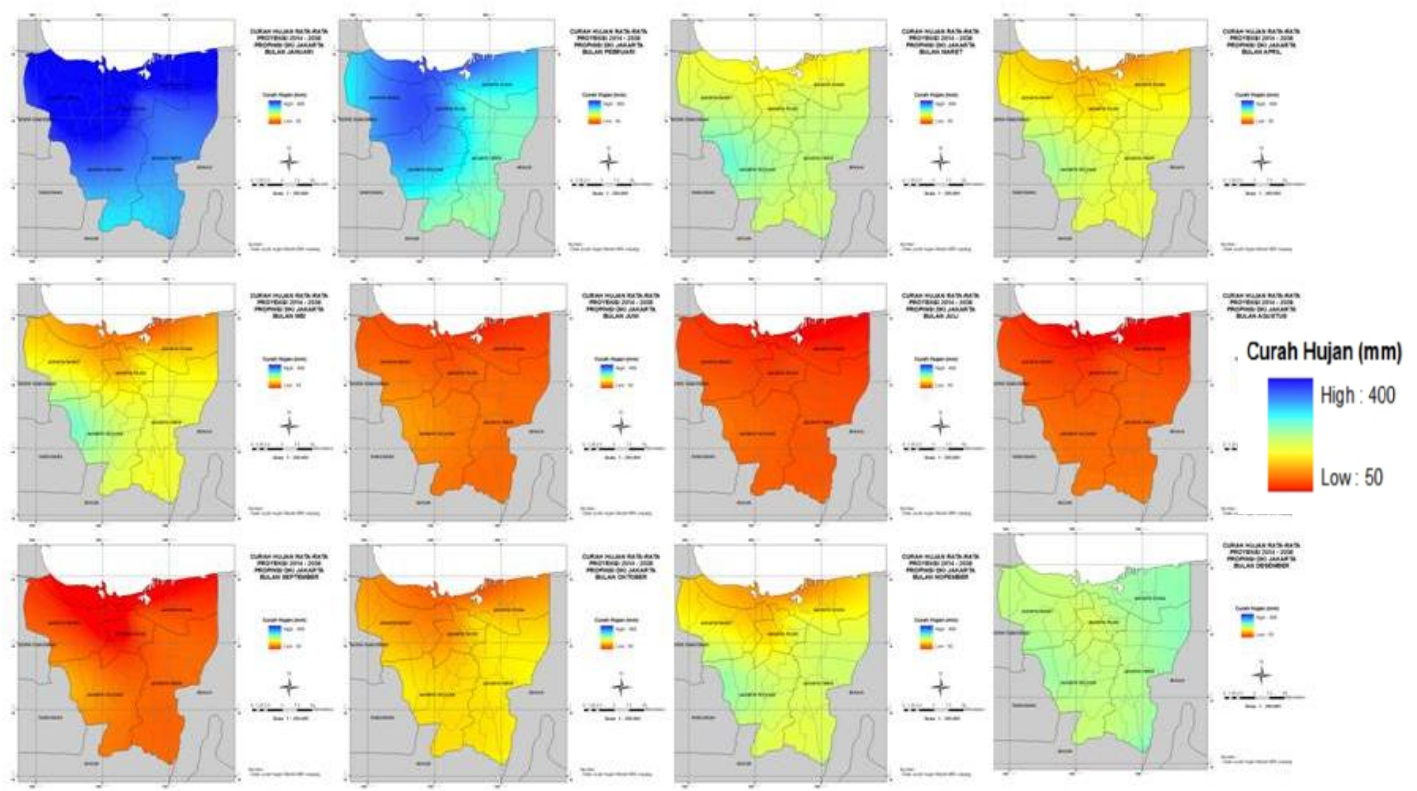

Gambar 6. Peta proyeksi curah hujan rata-rata bulanan (2014-2038)

\section{Proyeksi Peluang Demam Berdarah}

Proyeksi peluang DBD untuk tiga klasifikasi yaitu klasifikasi resiko rendah, menengah dan tinggi, berdasarkan input proyeksi temperatur dan curah hujan mendapatkan hasil bahwa wilayah Jakarta masih berpeluang tinggi untuk berada pada resiko tinggi DBD (kasus DBD > 55). Mengacu pada laporan Kementerian Kesehatan tahun 2010 dalam buletin data surveilance menyebutkan bahwa selama ini Jakarta selalu berada pada kategori Propinsi dengan resiko DBD tinggi. ${ }^{8}$

Dengan menggunakan persamaan model logistik 1,2 dan 3 diperoleh nilai proyeksi peluang demam berdarah seperti pada Tabel 1. Hasil perhitungan proyeksi peluang DBD menunjukan bahwa untuk klasifikasi resiko DBD rendah nilai peluangnya berkisar 0,0005-0,088, resiko DBD sedang nilainya 0,002-0,233 dan resiko DBD tinggi 0,74-0,99.

Berdasarkan perbandingan nilai peluang pada tiga kategori maka peluang resiko DBD tinggi nilainya lebih besar daripada dua kategori lainnya (resiko DBD rendah dan sedang). Hal ini mengindikasikan bahwa ke depan Jakarta masih tergolong kedalam wilayah dengan resiko DBD tinggi. Hasil proyeksi peluang ini juga menunjukan bahwa untuk periode 2014-2038 kondisi temperatur dan curah hujan masih memiliki keseuaian untuk siklus hidup/perkembangbiakan vektor nyamuk aedes Aegypti.

Tabel 1. Peluang DBD berdasarkan Proyeksi Curah Hujan $(\mathrm{CH})$ dan Temperatur $(\mathrm{T})$

\begin{tabular}{|c|c|c|c|}
\hline \multirow{2}{*}{ B u I a n } & \multicolumn{3}{|c|}{ Peluang DBD setiap Klasifikasi } \\
\cline { 2 - 4 } & Rendah & Sedang & Tinggi \\
\hline Jan & 0,00055 & 0,00245 & 0,99754 \\
\hline feb & 0,00152 & 0,00676 & 0,99323 \\
\hline Mar & 0,01359 & 0,05650 & 0,94349 \\
\hline Apr & 0,02665 & 0,10360 & 0,89639 \\
\hline Mei & 0,03432 & 0,12840 & 0,87159 \\
\hline Jun & 0,06904 & 0,21950 & 0,78049 \\
\hline Jul & 0,07224 & 0,22640 & 0,77359 \\
\hline Agust & 0,07563 & 0,23349 & 0,76650 \\
\hline Sep & 0,08850 & 0,25831 & 0,74168 \\
\hline Okt & 0,05676 & 0,19084 & 0,80915 \\
\hline Nop & 0,02300 & 0,09105 & 0,90894 \\
\hline Des & 0,01035 & 0,04378 & 0,95621 \\
\hline
\end{tabular}




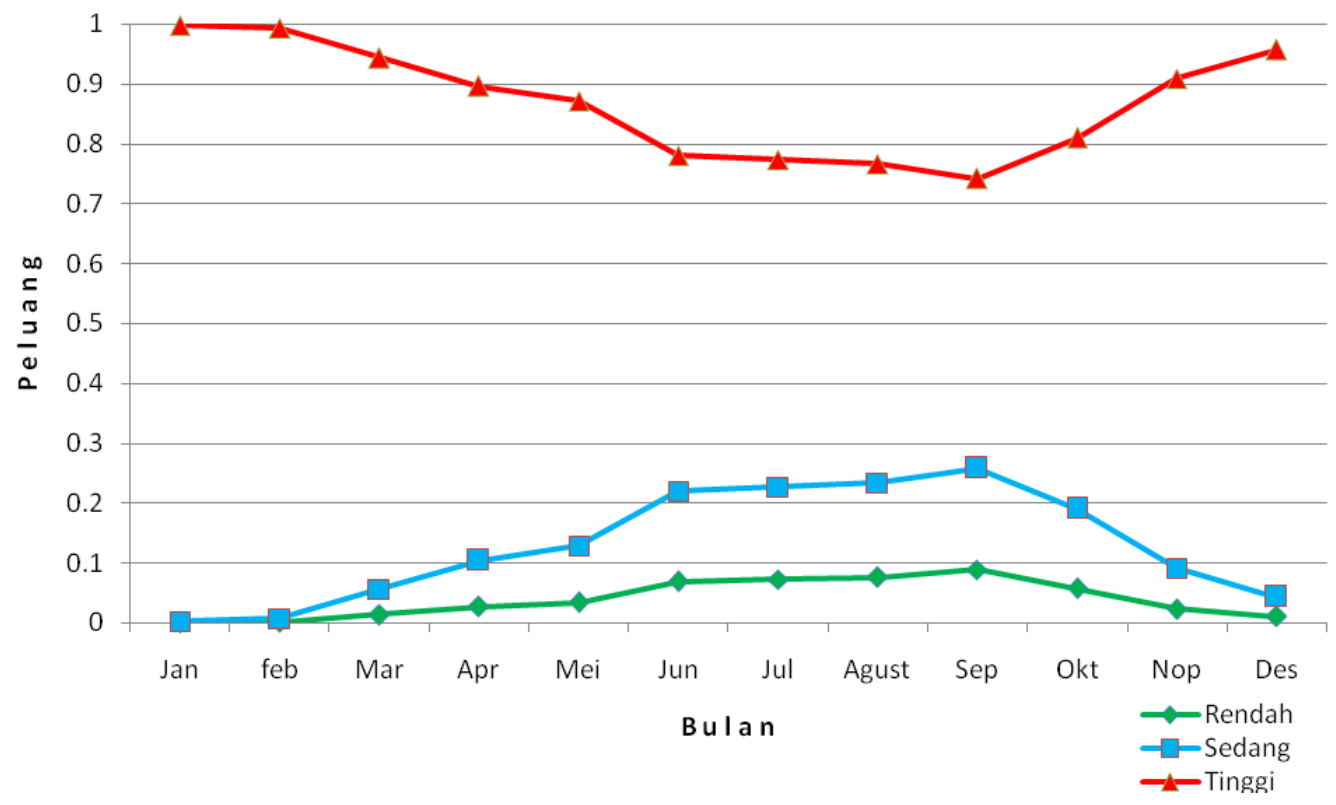

Gambar 8. Proyeksi peluang DBD rata-rata periode 2014-2038 (resiko rendah, sedang dan tinggi) berdasarkan proyeksi CH rata-rata dan T rata-rata periode 2014-2038

\section{PEMBAHASAN}

Berdasarkan hasil yang telai di uraikan sebelumnya, maka ada beberapa point pembahasan yang terkait tujuan dari kajian ini. Bahwa karena kondisi topografi relatif datar dan tutupan lahan Jakarta yang permukaannya sebagian besar ditutupi oleh bangunan-bangunan, maka dengan situasi atmosfir yang sudah dipenuhi oleh gas-gas karbon (efek gas rumah kaca), temperatur udara dipermukaan mengalami peningkatan (dirasakan semakin panas). Khusus bila dilihat dari sektor kesehatan, dengan adanya kenaikan temperatur maka akan terjadinya percepatan reproduksi vektor penyakit (nyamuk aedes Aegypti). Perlu ada tindakan preventif dalam hal penguatan kebijakan dalam menekan kesehatan lingkungan supaya tidak tercipta lingkungan baru yang optimum untuk pertumbuhan nyamuk. Untuk tindakan refresif dapat dengan teknologi dalam menciptakan obat-obatan/ pestisida yang ampuh dan ramah lingkungan dalam membasmi vektor penyakit.

Memperhatikan pola sebaran temperatur berdasarkan waktu (bulanan) sepanjang tahun seperti tampak pada gambar 3., kondisi temperatur udara relatif hangat berkisar antara $26-30^{\circ} \mathrm{C}$. Interval temperatur seperti ini sesuai dengan siklus hidup dan perkembangan nyamuk aedes Aegypti. ${ }^{7}$ Oleh karena itu penanganan terhadap perkembangan vektor penyakit DBD mutlak harus dilakukan dengan baik guna meminimalisir tingkat DBD yang akan terjadi. Sejalan dengan pola sebaran waktu pada temperatur, sebaran DBD di Jakarta terjadi sepanjang tahun dengan kriteria resiko tinggi.

Untuk proyeksi curah hujan 20142038, menurut hasil menunjukan sedikit perubahan tidak konsisten, pada bulan tertentu ada yang curah hujan mengalami peningkatan dan ada yang lebih rendah. Dengan kondisi demikian beberapa kemungkinan yang akan berdampak pada DBD adalah 1. Akan ada pergeseran waktu dan wilayah yang sesuai dengan perkembangan nyamuk, 2. Karena secara pola dan jumlah curah hujan relatif tidak jauh berbeda, maka kemungkinan kedepan intensitas curah hujan akan lebih tinggi, artinya bila pada saat ini curah hujan jatuh dalam 15-20 hari maka kedepan dimungkinan hanya terjadi dalam waktu (hari hujan) yang lebih sedikit, 3. 
Dengan tidak konsistennya curah hujan, maka dampak yang ditimbulkan akan sulit untuk di deteksi termasuk terhadap penyebaran vektor penyakit. Mengacu pada beberapa kemungkinan dari curah hujan, maka terkait kasus demam berdarah akan timbul lokasi-lokasi baru yang membuat peluang kejadian demam berdarah akan lebih meningkat.

Terkait hasil proyeksi peluang resiko DBD tinggi di Jakarta cukup signifikan (gambar 7.), maka peran curah hujan dan temperatur udara sebagai penyedia lingkungan dan pemicu perkembangan jentik nyamuk aedes Aegypti cukup berpengaruh. Hal ini tergambar dari kurva proyeksi peluang DBD pada gambar 7., yang menunjukan bahwa besar kecilnya nilai peluang ditentukan berdasarkan nilai proyeksi curah hujan dan temperatur. Pada kondisi curah hujan Intensitas tinggi dan menyebabkan bencana banjir, $\mathrm{CH}$ akan menghasilkan air limpasan sebagai penghanyut jentik pada genangan permukaan yang terlewati. Namun tidak demikian halnya untuk genangan yang berada di luar jangkauan air limpasan.

Tingginya proyeksi peluang DBD ke depan, dapat menjadi dasar bagi para pemangku kebijakan untuk menyiapkan langkah strategi adaptasi yang baik guna meminimalisir kasus DBD yang akan terjadi. Bagi masyarakat umum informasi ini mengindikasikan bahwa ke depan dengan pengalaman yang ada, mereka harus dapat mengambil langkah untuk mengantisipasi wabah penyakit DBD.

\section{KESIMPULAN}

Berdasarkan hasil analisis dan pembahasan, maka kesimpulan dari penelitian ini adalah proyeksi temperatur udara periode 2014-2038 menunjukan adanya peningkatan yang konsisten dengan jangkauan sebesar $0,3^{\circ} \mathrm{C}$, nilai ini akan berpengaruh terhadap percepatan reproduksi nyamuk aedes Aegypti sebagai penyebab DBD. Untuk proyeksi curah hujan, perubahannya tidak konsisten, ada bulan-bulan yang mengalami kenaikan curah hujan dan ada yang mengalami penurunan. Bulan Januari, Februari dan Nopember mempunyai curah hujan rata- rata dan proyeksi $\mathrm{CH}$ relatif tinggi yaitu 120 - $317 \mathrm{~mm}$, perlu mendapat perhatian lebih terkait ancaman bencana banjir dan wabah DBD. Untuk proyeksi peluang DBD ke depan, wilayah DKI Jakarta masih berpeluang tinggi tergolong dalam kategori wilayah resiko tinggi DBD dengan nilai peluang 0,74-0,99.

\section{SARAN}

Perubahan curah hujan dan temperatur udara meningkatkan peluang demam berdarah, informasi ini menjadi dasar bahwa ke depan perlu ada kebijakan yang tepat untuk dapat meminimalisir kejadian demam berdarah. Terkait rencana aksi nasional, maka perlu diambil langkah mitigasi untuk menahan laju perubahan iklim, dan adaptasi dalam menghadapi dampak yang akan terjadi.

\section{DAFTAR PUSTAKA}

1. IPCC working group II. 2007. Regional Vulnerable Impacts, adaptation and Vulneability. IPCC fourth assessment reports.

2. Aldrian E.,Karmini M., Budiman. 2011. Adaptasi dan Mitigasi Perubahan Iklim di Indonesia. Jakarta : Pusat Perubahan Iklim dan Kualitas Udara BMKG.

3. BMKG Reports. 2010. Seasonal Prediction : Wet and Dry Season Prediction. Jakarta : Pusat Iklim Agriklimat dan Iklim Maritim BMKG.

4. Hales, S., Edwards, S.J., Kovats, R.S., 2003. Impacts on Health of climate Change. Geneva : WHOWMO-UNEP.

5. Githeko, A. Dan Woodward, A., 2003. International Concensus on The Science of Climate Change. The IPCC Third Assessment Report.

6. WMO dan $\mathrm{WHO}, 2012$. Atlas of Health and Climate : Realizing the Potential to Improve Health Outcomes Through the Use of Climate Services. Switzerland : 


\section{WHO Press}

7. Tarmana, D., 2011. Potential Impact of Climate Change on Dengue Hermologic Fever (DHF) Disease in Indonesia. South Korea : Annual APCC Report 2012.

8. Team Bulletin data surveilance, 2010. Window of Epidemologi : Dengue Fever Cases. Jakarta : Ministry of Health.

9. Tarmana, D., dan Nuraidi, 2010. Identifikasi Potensi Dampak Perubahan Iklim terhadap Kesehatan (DBD) di Jakarta. Thesis : Institut Pertanian Bogor.

10. T.W. Anderson, 1984. An Introduction to Multivariate Statistical Analysis. Second Edition. John Wiley \& Sons.

11. Wigena, A.H., 2006. Pemodelan Statistical Downscaling dengan Regresi Projection Pursuit untuk Peramalan Curah Hujan Bulanan. Disertasi . IPB

12. M. J. Greenacre, 1993. Correspondence Analysis in Practice. Academic Press, Harcourt, Brace \& Company.

13. Agresti and Allan, 1996. An Introduction to Categorical Data Analysis. New York: John Wiley and Sons

14. Hosmer, D.W. and S. Lemeshow, 1989. Applied Logistic Regression. New York: John Wiley and Sons.

15. Kaiser, H.F., 1970. A Second Generation Little Jiffy. Psychometrika, 35, 401-405.

16. Kelley, T.L., 1942. The reliability coefficient. Psychometrika, 7, 75-85.

17. Linacre, J.M., 2008. Winsteps Rasch measurement (Version 3.63.2). Chicago, IL: MESA Press.

18. BMKG-ICCTF Reports, 2011. Public Awareness, Training And Education Programme on Climate Change Issue for All Level of Societies, Mitigation and Adaptation. Jakarta-
Indonesia

19. Ditjen P2PL, 2008. Impact of Global Warming, Dengue cases Increase. Jakarta : Tempo Interaktif 13 April 2008

20. Tarmana, D., And Aldrian, E., 2010. Vulnerability Maps of Dengue Hermologic Fever (DHF) in Jakarta. Jakarta :Joint Cooperation BMKG with Ministry of Health. 